\title{
Legal Analysis of State Financial Losses Returns in Corruption Crime Case in Indonesia
}

\author{
Amiruddin*, Achmad Ruslan, ${ }^{* *}$ M. Said Karim, ${ }^{* *}$ Syamsuddin Muchtar ${ }^{* * *}$ \\ *Doctoral Student, Faculty of Law, Hasanuddin University, Indonesia \\ ${ }^{* *}$ Professor, Faculty of Law, Hasanuddin University, Indonesia \\ ${ }^{* * *}$ Associate Professor, Faculty of Law, Hasanuddin University, Indonesia
}

\begin{abstract}
State finance is one of the main elements in the administration of state government and has very important benefits in realizing the country's goal of achieving a just and prosperous society as mandated in the opening of the 1945 Constitution of the Republic of Indonesia. By strengthening the institutional structure between law enforcement agencies and the division of tasks and functions of each rank of law enforcement in eradicating criminal acts of corruption and restoring state losses is a form of legal regulation to achieve professional, accountable and responsible performance in law enforcement.
\end{abstract}

Keywords: corruption, legal analysis, returns of state financial losses.

DOI: $10.7176 / \mathrm{IAGS} / 76-07$

Publication date:October $30^{\text {th }} 2019$

\section{Introduction}

The State of Indonesia is a state of law as mandated in the 1945 Constitution of the Republic of Indonesia as stipulated in Article 1 paragraph (3). This provision is the basis of state administration, in the sense that every implementation of the state must be based on applicable legal provisions. The source of national law is based on written provisions, in the sense of law made by the state which consists of laws and regulations. Whereas the sources of state law which were not made by the state such as religious law, customary law, customary law also included having binding power to every Indonesian citizen.

The role of law as the commander and foundation in the state so that all sectors of national life must be regulated and subject to the law, including in terms of recovering state losses that undermine the nation's economy if it wants to optimize state losses then it must also make the law as an instrument to optimize the regulation of loss recovery a country caused by corruptors. Without the existence of legal instruments used to regulate the recovery of state losses, corruption is increasingly rampant and increasingly fertile.

Corruption is an obligation of all parties to overcome it, because it is the mandate of the State's constitution in the context of implementing the government of the country to realize the objectives of the state which give rise to the rights and obligations of the state which can be valued in money. This means that the state has the right to receive repayments of state financial losses caused by corruptors, because the corrupted money includes state finances which are the rights and obligations of the state itself to own it. As stipulated in the provisions of Article 1 Paragraph (1) of the Law of the Republic of Indonesia Number 17 Year 2003 concerning State Finance, which regulates that "state finance is all rights and obligations of the state which can be valued in money and everything in the form of money or in the form of goods that can be become the property of the state in connection with the implementation of these rights and obligations". The implementation of the said state's rights and obligations has been regulated in Article 23C Chapter VIII of the 1945 Constitution of the Republic of Indonesia, which mandates other matters concerning state finances to be regulated by law.

The need for state finances is regulated by law because in the past few decades, corruption has been a rapidly developing crime in Indonesia. The flourishing corruption can be a source of disaster and especially for the Indonesian people. Various impacts caused by criminal acts of corruption, namely, corruption can cause catastrophic monetary crises that suddenly, which subsequently causes a decline in the people's economy and of course for the national economy in the form of state financial losses in the number of trillions of rupiahs; ${ }^{1}$ and create a high-cost economy that will leave people vulnerable to access to justice.

\footnotetext{
${ }^{1}$ Kompas, 4 June 2015. According to Deputy Coordinator of the Indonesia Corruption Watch (ICW), Ade Irawan that in 2014 the total state
} 
Corruption in Indonesia has become one of the problems of many other national problems. Corruption is suspected as the cause of economic collapse which has a negative impact on the occurrence of multi crises in almost all lines of life as a nation and state. Corruption that causes state financial losses that reach trillions of rupiah is not an easy matter to recover the state financial losses, but requires hard work by both government officials and law enforcement officials to optimize returns on the intended state financial losses into the state treasury.

Considering the state financial return is absolutely necessary and requires open and accountable management for the maximum benefit of the people's prosperity, which is realized in the State Budget and Regional Budget. This is in accordance with the provisions stipulated in Article 1 Paragraph (1) of the Law of the Republic of Indonesia Number 1 Year 2004 concerning State Treasury, which confirms that the state treasury is the management and accountability of state finances, including investments and assets that are separated, stipulated in the Revenue Budget and State Expenditures and Regional Revenue Expenditures.

That according to the Law of the Republic of Indonesia Number 15 Year 2006 concerning the Financial Examination Board, state finance is one of the main elements in the administration of state government and has very important benefits in realizing the country's goal of achieving a just and prosperous society as mandated in the opening of the 1945 Constitution of the Republic of Indonesia.

The management of state finances openly and responsibly is also the mandate of the 1945 Constitution of the Republic of Indonesia, as a state constitution which requires the management of state finances in an open and accountable manner in the framework of the administration of the state to realize the state's objectives that give rise to the country's rights and obligations. managed in a state financial management system. Because remembering this is a constitutional order and the repayment of state financial losses caused by corruptors in corruption cases is insignificant and far smaller compared to the amount of money corrupted and corrupted by corruptors in Indonesia which results in state financial losses very large even reaching trillions of rupiah. So, it certainly requires the availability of a legal umbrella in the form of regulations and other government regulations in order to facilitate legal arrangements for returning losses to state financial losses and with the existence of these legal regulation regulations, it can also be more optimal returns on state financial losses.

Indonesia as a country of law (rechtstaat), ${ }^{1}$ has a legal instrument from the substance side by enacting Law of the Republic of Indonesia Number 20 Year 2001 concerning Amendments to the Law of the Republic of Indonesia Number 31 Year 1999 concerning Eradication of Corruption Crimes that govern all formulations of criminal acts of corruption (materially) and formal pattern of case resolution.

Corruption crime based on the interpretation of the substance of the Law of the Republic of Indonesia Number 20 Year 2001 referred to above, can be classified as a form of misuse of the mandate for personal gain. Corruption is a subordination of the public interest under the interests of personal goals which include violations of norms, duties and public welfare coupled with betrayal or fraud of the consequences suffered by the wider community. $^{2}$

In the context of the eradication of corruption, experts point out that there are two determining factors that determine whether or not eradicating corruption crime in a rule of law such as in Indonesia. These two factors are the legal factors and the person factors. Legal factors can be interpreted as a form of seriousness of a rule of law in preparing a set of legal rules or norms that regulate all matters related to eradicating criminal acts of corruption. While the person factor is related to the ability and authority of law enforcement to understand and carry out the first factor, then apply it in a concrete situation in accordance with the demands of national legal ideals. For this reason, law enforcers need to have three things, namely knowledge, deep understanding and skills besides a deep sense of decency. ${ }^{3}$

Considering that there are legal instruments in the settlement of corruption cases in the form of the Law of the Republic of Indonesia Number 20 Year 2001 of the Republic of Indonesia, at least the state losses arising have legal accountability mechanisms. And with the law on corruption eradication, this is a form of government

losses due to corruption cases reached 5.29 trillion, while in 2015 according to ICW Investigation Division Staff Wana Alamsyah the total value of the state loss was in 2015 amounting to Rp. 31.077 trillion.

${ }^{1}$ The rule of law based on the teachings of the Pure Law (Reine Rechtslehre) from Hans Kelsen said that the state is nothing but a building of law itself. See Satjipto Rahardjo, 2009, Negara Hukum yang Membahagiakan Rakyatnya, Yogyakarta: Genta Publishing, p. 6-7

${ }^{2}$ Azis Syamsuddin, 2011, Tindak Pidana Khusus, Jakarta: Sinar Grafika, p. 137

${ }^{3}$ Sudarto, 1977, Hukum Pidana 1, Bandung: Alumni, p. 20 
efforts to optimize the regulation of the state of loss in addition to eradicating criminal acts of corruption in order to create an accountable, clean government of Corruption, Collusion and Nepotism as mandated by the Law of the Republic of Indonesia Number 28 Year 1999 concerning Implementing a Clean Government of Corruption, Collusion and Nepotism.

State financial losses resulting from the management of state finances that deviate or violate the law must be returned so that state finances are in their original state to finance the implementation of state government in order to achieve the country's objectives. ${ }^{1}$ The efforts of the state to recover the financial losses of the state have been prepared by legal instruments in the context of criminal law. The criminal legal instrument associated with recovering state financial losses through justice is Corruption Eradication Law. ${ }^{2}$

The Corruption Eradication Law contains legal norms related to legal actions that cause state financial losses. The legal act requires an appropriate resolution without violating human rights for the management of state finances as perpetrators of corruption offenses. For example, the rule of law in the Law of the Republic of Indonesia Number 20 Year 2001 relating to state financial losses namely Article 2 paragraph (1) of the Law on the Eradication of Corruption, regulates that "Any person who unlawfully commits an act of enriching himself or other people or a corporation that can harm the country's finances or the country's economy, are sentenced to life imprisonment or imprisonment for a minimum of four years and a maximum of twenty years and a fine of at least two hundred million rupiahs and a maximum of one billion rupiahs".

Article 2 paragraph (2) of the Law of the Republic of Indonesia Number 20 Year 2001 stipulates that "in the event that a criminal act of corruption as referred to in paragraph (1) is carried out in certain circumstances, the death penalty may be imposed". Furthermore, Article 3 regulates that "Anyone who has the purpose to benefit himself or another person or a corporation, misusing the authority, opportunity or means available to him, because of his position or position that can harm the country's finances or the country's economy, is convicted with imprisonment life imprisonment or imprisonment for a minimum of one year and a maximum of twenty years and/or a fine of at least fifty million rupiahs and a maximum of one billion rupiahs".

With regard to the formulation of the aforementioned articles of criminal acts of corruption, it reflects the meaning that how lawmakers have thought to make efforts to anticipate, prevent and minimize the greater state losses so as to give birth to this law. As well as on the other hand, the primary motivation for eradicating corruption is the law to maximize the return on state losses. Due to the existence of this law, there is room for legal regulation to recover maximum state losses through replacement money or fines for someone who enriches himself or others or a corporation that can harm the country's finances or the country's economy.

Because if it does not recover state financial losses in cases of corruption, there are more severe criminal sanctions awaiting the form of basic prison sentences and additional imprisonment sentences for someone who causes state or economic losses to the state by enriching oneself or another person or a corporation. Unlike the case before the promulgation of the Law of the Republic of Indonesia Number 31 Year 1999, in which state losses incurred were almost non-refundable, state finances were corrupted either by officials or someone who enriched themselves or others or a corporation, otherwise just disappeared without any strict legal liability.

Even though previously there was also a law to eradicate corruption, namely the Law of the Republic of Indonesia Number 3 Year 1971, the existence of this law does not have the fangs to eradicate corruption optimally, thus causing the country to suffer economic decline and its development is stagnant and underdeveloped compared to with other countries. However, after the entry into force of the Law of the Republic of Indonesia Number 31 Year 1999 as amended by the Law of the Republic of Indonesia Number 20 Year 2001, it gives a significant color to the accountability of state finances, in the sense that state finance is no longer corrupt and does not disappear just like that. In fact, most people in this country have begun to fear corruption, both individually and collectively because of the existence of this law which can provide a deterrent effect for perpetrators with the provision of a maximum sentence of 20 years imprisonment or life imprisonment. Along with the existence of the Corruption Eradication Commission institution which was born as an institution that functions to prevent and eradicate corruption crime in the country.

\footnotetext{
${ }^{1}$ Muhammad Djafar Saidi, et.al., 2017, Hukum Keuangan Negara Teori dan Praktik, Jakarta, PT. Raja Grafindo Persada, p. 180-181

${ }^{2}$ Ibid.
} 
Even though up to now, corruption cannot be eroded to its roots, but at least with the law on corruption eradication, it can minimize the loss of state finances and narrow the space for corruptors to undermine the country's larger economy, because the law on corruption eradication contains the threat of sanctions that can make impoverishment poor and deterrent for perpetrators. Because the property is confiscated to be returned to the state financial loss or at least punished to pay compensation and fines for state losses, due to actions that enrich themselves or others or corporations that cause financial losses to the state or the country's economy, and also no less important is the existence the threat of imprisonment is a severe corporal sentence imposed on corruptors who are involved in state finances.

With the issuance of the Law of the Republic of Indonesia Number 20 Year 2001 concerning Amendments to the Law of the Republic of Indonesia Number 31 Year 1999 concerning Eradication of Corruption, as explained above, is a response from the state due to the rampant mode of criminal acts of corruption which is suspected as a form of extraordinary crime that results in social, economic inequality, loss of government trust and various other problems. The aforementioned law is not merely its main purpose as an effort to optimize the government or lawmakers to overcome corrupt behavior so that it will not grow and flourish in Indonesia, because it cannot be imagined and illustrated how this country will become if the provisions The Corruption Eradication Act has not yet been enacted. However, the existence of these regulations as regulations to eradicate corruption will have an extraordinary impact in contributing to the development of the nation's economy. Because with the presence of this law can function as a legal arrangement in preventing corruption and as a legal arrangement for the optimal return of state financial losses that have been corrupted by a person or corporation that aims to benefit themselves or others and their groups that harm the country's finances.

The facts show that the existence of the Law of the Republic of Indonesia Number 20 Year 2001 is still incomplete and incomplete. Bearing in mind that these laws and regulations do not regulate seizure and/or confiscation of property belonging to the accused or the convicted person so that it does not result in an optimal return of state losses. According to the opinion of the author in order to optimize the return of state losses, it is necessary to amend or revise the corruption eradication law, by including confiscation or seizure of property belonging to the accused or convicted as one of the elements of the article in the corruption eradication law so that the return of state losses can be more maximum.

The optimization of legal arrangements to recover state financial losses has the existence and urgency that is very important for the continuity of the economy and the overall development of the nation. Because with the return of state financial losses through enforcement and legal regulation in corruption cases, it can create a healthy state economic climate and only with a healthy economy, the state can fill and implement development well in all fields. Conversely, if the economy is unhealthy, of course the country will stumble and stumble in carrying out the wheels of development activities whose impact will also be felt again by the community itself. Thus, optimizing the arrangement of legal arrangements to repay losses of state financial losses is very important, in order to recover the losses of state finances better and more professional so that the repayment of state financial losses from the results of criminal acts of corruption can be arranged into the state treasury with optimal results as expected. One form of legal arrangements for repayment of state financial losses in cases of criminal acts of corruption, is the existence of special minimum criminal provisions in the formulation of the offense against perpetrators of criminal acts of corruption. Considering, due to the special minimal criminal provisions that are applied to the formulation of offense for corruptors, there is a suggestion and a very deep psychological burden on corruptors to immediately recover the financial losses of the state immediately. Because the ratio of the special minimum criminal provisions that are applied to the formulation of the offense in the case of a criminal act of corruption is qualified as an offense that contains an element of weighting, which differs from the general criminal provisions known in the Criminal Code which are more familiar with maximum criminal provisions.

It is logical that lawmakers formulate specific minimum criminal provisions in cases of corruption which are based on several judicial considerations or reasons as described by criminal law expert Barda Nawawi Arief as follows: ${ }^{1}$

- There is a very striking fact of disparity for offenses that are essentially no different in quality;

\footnotetext{
${ }^{1}$ Barda Nawawi Arief, 2002, Bunga Rampai Kebijakan Hukum Pidana, Bandung: Citra Aditya, p. 125
} 
- There is a desire to meet the demands of the community which requires the existence of minimum objective standards for certain offenses which are highly denounced and harm/endanger the community/country, as well as offenses which are accredited or exacerbated by the consequences;

- There is a desire to make the effect of general intervention more effective on certain offenses that are considered harmful and disturbing to the community.

Returns of state financial losses in cases of corruption is very much in need and requires adequate regulation of legal arrangements, as a basis for maximum withdrawal of state finances in the hands of corruptors. In fact, ideally, it is not enough just to provide legal instruments in the form of the Law of the Republic of Indonesia Number 20 Year 2001 as a legal umbrella, but legal arrangements are also needed in an effort to optimize returns on state losses in cases of acts of corruption. Especially related legal arrangements regarding restrictions on taking legal action on appeal, cassation and judicial review of certain corruption cases which limit the amount of loss to the country of only tens of millions to hundreds of millions of rupiah. In order to be limited and or no longer allowed to appeal, appeal and review after the first court verdict which states that the perpetrators of corruption have been proven legally and convincingly to commit acts of corruption to enrich themselves, others or corporations so as not to drag on and too long the bureaucracy returns the state's financial losses.

In cases of such criminal acts of corruption, then the Supreme Court should make a breakthrough by issuing regulations or circular of the Supreme Court concerning the nominal limits on cases of corruption that may or may not, take legal action on appeal, appeal or review, without neglecting the regulations for the eradication of corruption itself, in order to optimize and accelerate the recovery of state financial losses in the case of corruption and to realize legal certainty for the public in a relatively short time. So that the role of judges is not only the mouthpiece of legislators, but autonomously, creating, delving into the social process. ${ }^{1}$ And by itself can be realized legal decisions that are coveted, namely decisions that contain aspects of justice, legal certainty and expediency. ${ }^{2}$ Based on the explanation, the problem that will be discussed in this paper is how is the legal arrangement to returns state financial losses? and how is the handling of corruption in Indonesia?

\section{Research Method}

This type of research is normative using the statute approach and conceptual approach. ${ }^{3}$ The data used are secondary data collected through literature searches and documentation studies. The collected data is then analyzed qualitatively and then described.

\section{Results and Discussion}

\section{A. Legal Arrangement to Returns State Financial Losses}

Legislation as a legal product becomes a very important tool in the implementation of state life. ${ }^{4}$ Returns state financial losses in cases of corruption is not an easy matter but requires hard work and optimal legal regulation in order to produce results in recovering state losses. Because only with a maximum legal arrangement the loss of state finances can be returned to the state treasury well, because without legal arrangements it is impossible for state losses, to be managed and arranged with an optimal return. Included in the case of institutional law enforcement is something that is absolutely necessary because it is vital and urgent to determine the success or failure of returning state losses, especially regarding the distribution of job descriptions or the division of tasks and functions that must be in line and harmonious between law enforcement agencies both institutions police, prosecutors, the Corruption Eradication Commission and the court in eradicating corruption and returning state financial losses.

Only at a certain level the sanctions are no longer balanced, so it needs tougher and heavier sanctions that are accompanied by criminal sanctions. ${ }^{5}$ The Law of the Republic of Indonesia Number 20 Year 2001

\footnotetext{
${ }^{1}$ Sudikno Mertokusumo and A. Pilto, 1993, Bab-Bab tentang Penemuan Hukum, Jakarta: Citra Aditya Bakti, p. 7

2 Bambang Sutiyoso, 2006, Metode Penemuan Hukum: Upaya Mewujudkan Hukum yang Pasti dan Berkeadilan, Yogyakarta: UII Press, p. 28

${ }^{3}$ Peter Mahmud Marzuki, 2005, Penelitian Hukum, Jakarta: Prenadamedia Group, p. 35

4 Achmad Ruslan, 2011 Peraturan Perundang- $U^{\text {ndangan Sebagai Sarana Hukum Penyelenggaraan Negara, Professor's Oration }}{ }^{.}{ }^{.6}$

${ }^{5}$ S.R. Sianturi, 1986, Asas-Asas Hukum Pidana dan Penerapannya, Jakarta: Alumni Ahaem Petehaem, p. 25; See also Andi Sofyan and Nur Azisa, 2016, Hukum Pidana, Makassar: Pustaka Pena Press, p. 7
} 
concerning Amendment to the Law of the Republic of Indonesia Number 31 Year 1999 concerning Eradication of Corruption Crimes is expected that these law enforcement agencies must work together and work hand in hand in combating widespread and systematic corruption as well as returning state losses in a systematic manner. maximum. So that only with law enforcement synergizing between law enforcement institutions, corruption can be reduced and minimized and the state's return of losses can be maximized. Without all of this, it is impossible for the crime of corruption to be overcome and the optimal return of state losses. Because corruption is a crime that occurs systematically and is widespread so that it not only harms state finances, but also has violated the social and economic rights of the community at large so that the handling must also be carried out in an extraordinary manner (extra ordinary crime). One of the supporting factors in handling the case of widespread corruption has been institutional strengthening and synergy between law enforcement agencies so that they can young and quickly eradicate corruption. Synergy and institutional strengthening between law enforcement is absolutely necessary in handling extraordinary crimes such as corruption and other similar crimes, in order to prevent and ward off corrupt or corrupt criminal acts that undermine and damage the joints of the nation's economy.

The Due Process Model is one model that supports the criminal justice system because it separates the authority of various bodies in the criminal justice system. ${ }^{1}$ By strengthening the institutional structure between law enforcement agencies and the division of tasks and functions of each rank of law enforcement in eradicating criminal acts of corruption and restoring state losses is a form of legal regulation to achieve professional, accountable and responsible performance in law enforcement. The milestone in optimizing the legal regulation in eradicating criminal acts of corruption reached its climax after the promulgation of the Law of the Republic of Indonesia Number 20 Year 2001 concerning Amendments to the Law of the Republic of Indonesia Number 31 Year 1999 concerning Eradication of Corruption Crimes. Because with the birth of this law legal arrangements in the eradication of criminal acts of corruption are increasingly increasing, free and fast eradication of criminal acts of corruption which also causes the impact of the swift return of state losses in cases of corruption in the state treasury and corruption behavior decreases from year to year due to incessant eradication of criminal acts of corruption committed by law enforcement officials with the existence of the law as a legal basis.

\section{B. Corruption Prevention in Indonesia through the Facilities of Criminal Law}

Every state loss is caused by perpetrators of corruption, both those that are still in the country and those already outside the country must be returned, through the mechanism of international cooperation which is an absolute thing to do. ${ }^{2}$ Indonesia is one of the countries that has a strong commitment in combating corruption. This can be seen from the various policies and regulations that have been issued by the Government of the Republic of Indonesia. Since the days of the old order, the new order and the reform order have formed a variety of special institutions related to the eradication of corruption, including: Establishment of the Commission on the Examination of the Wealth of State Administrators (Presidential Decree of the Republic of Indonesia Number 18 Year 1999), Acceleration of Corruption Eradication (Indonesian Presidential Instruction Number 5 Year 2004), Establishment of the Corruption Eradication Coordination Team (Presidential Decree of the Republic of Indonesia Number 11 Year 2005), Cooperation between the Corruption Eradication Commission and the Indonesian Attorney General's Office in eradicating corruption (Joint Decree of the Chairman of the Corruption Eradication Commission and the Attorney General of the Republic of Indonesia), Establishment The Legal Mafia Eradication Task Force (Presidential Decree of the Republic of Indonesia Number 37 Year 2009), the Law of the Republic of Indonesia Number 30 Year 2002 concerning Corruption Eradication Commission, the Law of the Republic of Indonesia Number 28 Year 1999 concerning State Administrators that are Implementing a Clean Government of Corruption, Collusion and Nepotism. In addition, the government together with the Indonesian legislature made changes to the Law of the Republic of Indonesia Number 3 Year 1971 concerning Corruption with the Law of the Republic of Indonesia Number 31 Year 1999 juncto the Law of the Republic of Indonesia Number 20 Year 2001 and the Law of the Republic of Indonesia Number 7 Year 2006 concerning ratification "United Nations Convention Against Corruption (UNCAC) 2003".

According to Romli Atmasasmita ${ }^{3}$ that the strategy to eradicate corruption in Indonesia must use four approaches, namely the legal approach, the moralistic and faith approach, the educational approach and the socio-cultural approach; in this case, the legal approach plays a very strategic role, but the conventional legal

\footnotetext{
${ }^{1}$ M. Said Karim, 2019, Ganti Kerugian Terhadap Korban penangkapan yang Tidak Sah dalam Proses Peradilan Pidana, Makassar: Pustaka Pena Press, p. 68

${ }^{2}$ Kadarudin, 2015, Asset Recovery Hasil Kejahatan Korupsi: Upaya Pengembalian Kerugian Keuangan Negara Melalui Kerjasama Internasional, Pustaka Pena Press, Makassar, p. 87

${ }^{3}$ Ermasjah Djaja, 2010, Memberantas Korupsi Bersama Komisi Pemberantasan Korupsi, Jakarta: Sinar Grafika, p. 10
} 
approach is inadequate in dealing with the modus operandi of corruption that is systematic and widespread and constitutes "extraordinary ordinary crimes". For this reason, a new legal approach is needed that places the interests of the nation and state or the economic and social rights of the people above the interests and rights of individual suspects or defendants.

In the government statement in the discussion of the Law of the Republic of Indonesia Number 31 Year 1999, it was stressed that the purpose of the Law of the Republic of Indonesia Number 31 Year 1999 was submitted with four basic considerations:

a. Strengthening the legal basis in an effort to eradicate corruption that is increasingly modern and difficult to prove.

b. Prevent greater loss of state finances.

c. Increasing the effect of prevention even greater potential actors, and;

d. Fostering confidence in the community at home and abroad for law enforcement in Indonesia in corruption cases.

\section{Conclusion}

Legal arrangements for returns of state financial losses are stipulated in the Law of the Republic of Indonesia Number 20 Year 2001 concerning Amendments to the Law of the Republic of Indonesia Number 31 Year 1999 concerning Eradication of Corruption, and overcoming corruption in Indonesia through criminal legal means, namely synergy between law enforcers in enforcing the law professionally and with integrity, this can be seen from the collaboration between the Corruption Eradication Commission and the Indonesian Attorney General's Office in the eradication of corruption.

\section{References}

Achmad Ruslan, 2011, Peraturan Perundang-Undangan Sebagai Sarana Hukum Penyelenggaraan Negara, Professor's Oration.

Andi Sofyan and Nur Azisa, 2016, Hukum Pidana, Makassar: Pustaka Pena Press.

Azis Syamsuddin, 2011, Tindak Pidana Khusus, Jakarta: Sinar Grafika.

Bambang Sutiyoso, 2006, Metode Penemuan Hukum: Upaya Mewujudkan Hukum yang Pasti dan Berkeadilan, Yogyakarta: UII Press.

Barda Nawawi Arief, 2002, Bunga Rampai Kebijakan Hukum Pidana, Bandung: Citra Aditya.

Ermasjah Djaja, 2010, Memberantas Korupsi Bersama Komisi Pemberantasan Korupsi, Jakarta: Sinar Grafika. Kadarudin, 2015, Asset Recovery Hasil Kejahatan Korupsi: Upaya Pengembalian Kerugian Keuangan Negara Melalui Kerjasama Internasional, Pustaka Pena Press, Makassar.

M. Said Karim, 2019, Ganti Kerugian Terhadap Korban penangkapan yang Tidak Sah dalam Proses Peradilan Pidana, Makassar: Pustaka Pena Press.

Muhammad Djafar Saidi, et.al., 2017, Hukum Keuangan Negara Teori dan Praktik, Jakarta, PT. Raja Grafindo Persada.

Peter Mahmud Marzuki, 2005, Penelitian Hukum, Jakarta: Prenadamedia Group.

S.R. Sianturi, 1986, Asas-Asas Hukum Pidana dan Penerapannya, Jakarta: Alumni Ahaem Petehaem.

Satjipto Rahardjo, 2009, Negara Hukum yang Membahagiakan Rakyatnya, Yogyakarta: Genta Publishing.

Sudarto, 1977, Hukum Pidana 1, Bandung: Alumni.

Sudikno Mertokusumo and A. Pilto, 1993, Bab-Bab tentang Penemuan Hukum, Jakarta: Citra Aditya Bakti. 